\title{
MIR208A Gene
}

National Cancer Institute

\section{Source}

National Cancer Institute. MIR208A Gene. NCI Thesaurus. Code C81791.

This gene is involved in the regulation of gene expression and plays a role in the development of cardiac hypertrophy. 